\title{
Evaluation of Functional Properties in Protein Hydrolysates from Bluewing Searobin (Prionotus punctatus) Obtained with Different Microbial Enzymes
}

\author{
Sarita D’Avila dos Santos • Vilásia Guimarães Martins • \\ Myriam Salas-Mellado • Carlos Prentice
}

Received: 18 March 2009/Accepted: 23 November 2009/Published online: 18 December 2009

(C) Springer Science+Business Media, LLC 2009

\begin{abstract}
Enzymatic hydrolysis of proteins from low commercial value fish could be produced for uses like functional ingredients in a wide and always increasing zone of application in different food products. The objective of this work was to evaluate the functional properties and the amino acid profile of enzymatic hydrolysates from Bluewing searobin (Prionotus punctatus), using two microbial enzymes, Alcalase and Flavourzyme. The enzymatic hydrolysate obtained through the addition of the enzyme Alcalase reached the maximum solubility $(42 \%)$ at $\mathrm{pH} 9$, water holding capacity (WHC) of $2.4 \mathrm{~g}_{\text {water }} \mathrm{g}_{\text {protein }}{ }^{-1}, 4.5 \mathrm{~g}_{\text {oil }}$ $\mathrm{g}_{\text {protein }}{ }^{-1}$ of oil holding capacity (OHC) and an emulsifying activity index (EAI) of $54 \mathrm{~m}^{2} \mathrm{~g}_{\text {solids }}{ }^{-1}$ at $\mathrm{pH} 3$. On the other hand, the hydrolysate obtained from Flavourzyme attained $38 \%$ of solubility at $\mathrm{pH} 9,3.7 \mathrm{~g}_{\text {water }} \mathrm{g}_{\text {protein }}{ }^{-1}$ and $5.5 \mathrm{~g}_{\text {oil }}$ $\mathrm{g}_{\text {protein }}{ }^{-1}$ for the holding capacities, and an EAI of $71 \mathrm{~m}^{2} \mathrm{~g}_{\text {solids }}{ }^{-1}$ at $\mathrm{pH} 11$. The hydrolysate with Flavourzyme produced best results for WHC, OHC, and EAI because it had solubility lower than the hydrolysate of Alcalase. The hydrolysate produced by Alcalase had a higher amino acid content compared with Flavourzyme's hydrolysate. However, both showed a good essential amino acid amounts. In general, these results indicate the potential utilization of the hydrolysate from Bluewing searobin in food formulations for the direct human consumption.
\end{abstract}

Keywords Fish · Enzymatic hydrolysates · Alcalase . Flavourzyme $\cdot$ Functional properties

S. D. dos Santos • V. G. Martins • M. Salas-Mellado •

C. Prentice $(\triangle)$

Laboratório de Tecnologia de Alimentos,

Escola de Química e Alimentos,

Universidade Federal do Rio Grande, Rua Alfredo Huch, 475,

96201-900 Rio Grande, RS, Brazil

e-mail: dqmprent@furg.br

\section{Introduction}

The exploitation of natural resources and increased environmental pollution have stressed the need for more valued use of residues generated by the fish processing plants and species with low commercial value. Bluewing searobin is a fish captured in abundance in the South of Brazil, and it has a low commercial value.

Enzymatic hydrolysis is an efficient approach for solubilizing fish protein. The yield of soluble materials which constitutes the final product of hydrolysis depends on factors such as the type of enzyme, substrate, and the hydrolysis conditions including $\mathrm{pH}$, temperature, incubation time, and enzyme concentration (Adler-Nissen 1986).

Protein hydrolysates are used widely in the food industry for various purposes, such as milk replacers, protein supplement, surimi production, beverage stabilizers, and flavor enhancers (Skanderby 1994). Fish protein hydrolysates, obtained by controlled enzymatic hydrolysis, have good nutritional properties such as balanced amino acid composition and high digestibility but are mainly used for animal nutrition (Nolsoe and Undeland 2009).

An advantage found in subjecting fish meat to enzymatic hydrolysis is the ability to modify and enhance the functional properties of fish proteins. Those proteins are important, particularly in their use as food ingredients (Gildberg 1993).

Enzymatic hydrolysis of fish protein generates a mixture of free amino acids, di-, tri-, and oligo-peptides; increases the number of polar groups and the solubility of hydrolysate compounds; and, therefore, changes the functional characteristics of proteins, improving their functional quality and availability (Mullally et al. 1995).

Proteases such as Alcalase and Flavourzyme have been reported to hydrolyze fish protein efficiently (Kristinsson 
and Rasco 2000; Normah et al. 2005; Dumay et al. 2006; Safari et al. 2009; Martins et al. 2009).

Functional properties are related to structure of proteins, such as the sequence and composition of amino acids, molecular weights, conformation, and charge distributed on the molecule (Casarin et al. 2008). The charge's nature and density facilitate interactions with other components, such as water, ions, lipids, carbohydrates, vitamins, color, and flavor constituents, which depend on factors as $\mathrm{pH}$, temperature, ionic strength, which are in turn involved during food preparation, processing, and storage (Rosa 2000; Lempek et al. 2007).

The objective of this work consisted in evaluating the properties of enzymatic hydrolysate compounds from Bluewing searobin, prepared with microbial enzymes Alcalase and Flavourzyme, in order to direct their use towards the best applications in products for direct human consumption.

\section{Materials and Methods}

\section{Raw Material}

Bluewing searobin (Prionotus punctatus) caught in South Atlantic Ocean and immediately frozen once on board, obtained from Pescal Fish Ind. \& Co. (Rio Grande, Southern Brazil), was used. Fish was transported in ice-filled containers to the Laboratory of Food Technology at University of Rio Grande (about $15 \mathrm{~min}$ ), where processing was placed. Then, fish was immediately washed with chlorinated water, beheaded, eviscerated, and filleted. Fillets were placed in plastic containers and stored frozen at $-18^{\circ} \mathrm{C}$, pending use.

\section{Raw Material Characterization}

Fillets were homogenized and characterized as to their physical ( $\mathrm{pH}$ and yield) and chemical (protein, fat, moisture, and ash) characteristics. The $\mathrm{pH}$ was measured through a countertop potentiometer, and the yield was calculated from the initial weight of the fish relative to the weight of the fillets obtained, which provided the determination of the final mass balance for the process. Crude protein was estimated by multiplying total $\mathrm{N}$ by 6.25 . Other analyses were performed according to AOAC (1995). Analyses were performed in triplicate.

\section{Microbial Enzymes}

The enzymatic process was performed with Alcalase and Flavourzyme. Alcalase is a bacterial endopeptidase produced by Bacillus licheniformis. Alcalase $2.4 \mathrm{~L}$ with a declared activity of 2.4 Anson Units (AU) $\mathrm{g}^{-1}$ has optimum enzymatic activity between 50 and $70^{\circ} \mathrm{C}$, and at $\mathrm{pH}$ values between 6 and 10 (Diniz and Martin 1996; Guerard et al. 2007). Flavourzyme is a fungal protease/peptidase complex produced by submerged fermentation of a selected strain of Aspergillus oryzae. Optimum working conditions reported for Flavourzyme $500 \mathrm{~L}$ (with declared activity of $500 \mathrm{~L}$ Aminopeptidase Units (APU) $\mathrm{g}^{-1}$ ) include $\mathrm{pH} 5$ to 7 , with an optimum temperature around $50^{\circ} \mathrm{C}$ (Slizyte et al. 2005). All of the following analyses were performed in triplicate. Both enzymes were produced by Novozymes A/S (Araucaria, Brazil) and comply with the recommended purity specifications for food-grade enzymes.

\section{Specific Activity for the Enzymes}

The specific activity of both enzymes was determined through the method described by Rebeca et al. (1991) adjusted to laboratory conditions. Hydrolysis was conducted having casein $(2 \%)$ and fish fillet ( $2 \%$ protein) as substrate, at $\mathrm{pH} 7$, temperature $40^{\circ} \mathrm{C}, 1 \%$ of enzyme $\left(\mathrm{p} \mathrm{p}^{-1}\right)$, and a 2-h reaction. One activity unit $(\mathrm{U})$ corresponds to the release of $1 \mu \mathrm{mol}$ of tyrosine per minute.

\section{Hydrolysis Process}

In order to obtain the hydrolysate protein compound, the sample was homogenized with a buffer corresponding to the desired $\mathrm{pH}$. Hydrolysis was conducted in two serially connected, enclosed and open $250-\mathrm{mL}$ glass reactors, along with an ultra-thermostatic water bath (QUIMIS ${ }^{\circledR}$, model 214. D2) and two helix stirrers (TECNAL, model TE-039/1, and QUIMIS ${ }^{\circledR}$, model Q-251D2K). In order to begin hydrolysis, the enzyme was added, controlling the temperature, $\mathrm{pH}$, and reaction time. The inactivation of the enzyme took place by heating in a $90^{\circ} \mathrm{C}$ water bath for $15 \mathrm{~min}$, and the hydrolysate compounds were dried in a $60^{\circ} \mathrm{C}$ circulation oven for $10 \mathrm{~h}$. The residual water was around $10 \%$ in all samples after this period. Those conditions were determined previously by Santos et al. (2009), in which the hydrolysate compounds obtained the highest degrees of hydrolysis.

\section{Statistical Analysis}

All assessed parameters are described in Table 1. The results were evaluated using analysis of variance (ANOVA); the post hoc test used was Tukey. These parameters were determined in a previous work (Santos et al. 2009) which was done in a complete factorial design $2^{3}$, and then the appropriate value for each parameter used in this study was indentified.

Determination of the Degree of Hydrolysis (DH)

Reaction was inactivated by adding a $6.25 \%$ solution of trichloroacetic acid. After resting for $10 \mathrm{~min}$, proteins were 
Table 1 Conditions for enzymatic hydrolysis reactions

\begin{tabular}{lcc}
\hline & Alcalase & Flavourzyme \\
\hline Temperature $\left({ }^{\circ} \mathrm{C}\right)$ & 70 & 50 \\
$\mathrm{pH}$ & 7.5 & 7.5 \\
Substrate concentration $\left(\mathrm{mg} \mathrm{mL} \mathrm{mL}^{-1}\right)$ & 500 & 500 \\
Enzyme concentration $\left(\%, \mathrm{p} \mathrm{p}^{-1}\right)$ & 0.5 & 3 \\
Reaction time $(\min )$ & 60 & 120 \\
DH $(\%)$ & 34.7 & 30.0 \\
\hline
\end{tabular}

quantified through the method by Lowry et al. (1951). Samples were read in a spectrophotometer Kary 100 visible UV at $750 \eta \mathrm{m}$. Degree of hydrolysis (DH) was measured according to the method described by Hoyle and Merritt (1994) and by Liceaga-Gesualdo and Li-Chan (1999) computed according to Eq. 1.

$D H=\frac{N_{\text {solubleTCA6,25\% }}}{N_{\text {sampletotal }}} \times 100$

Determination of Functional Properties

\section{Solubility (S)}

The solubility of the hydrolysate compounds from Bluewing searobin was determined according to Morr et al. (1985) with a $\mathrm{pH}$ variation in the range of 3 to 11 . Two milliliter of a $0.1-\mathrm{M} \mathrm{NaCl}$ solution was added to $500 \mathrm{mg}$ of dry sample, forming a homogenous paste. A buffer solution was added to the solution with the corresponding $\mathrm{pH}$ up to a volume of $40 \mathrm{~mL}$. The protein dispersion was kept under stirring for $45 \mathrm{~min}$. The dispersion was transferred to a $50-\mathrm{mL}$ volumetric glass, the volume being completed with the buffer solution. The protein dispersion was centrifuged at $6,000 \times \mathrm{g}$ for $30 \mathrm{~min}$. Aliquots were taken from the supernatant in order to identify the soluble protein content, through the method described by Lowry et al. (1951). The solubility rate was determined according to Eq. 2.

$S=\frac{A \times 50}{W \times \frac{P}{100}} \times 100$

where $A$ is the protein concentration in the supernatant ( $\left.\mathrm{mg} \mathrm{mL}^{-1}\right), W$ is the weight of the samples $(\mathrm{mg})$, and $P$ is the percentage of protein in the sample.

\section{Water (WHC) and Oil (OHC) Holding Capacity}

The capacity to hold water and oil was determined according to the methodology described by El Khalifa et al. (2005) adjusted to laboratory conditions. For the water holding capacity (WHC), $1 \mathrm{~g}$ of each hydrolysate compound was placed in previously weighted centrifuge tubes, and $14 \mathrm{~mL}$ of water was added. For the oil holding capacity (OHC), $14 \mathrm{~mL}$ of corn oil was added. Both samples were stirred in a tube stirrer and kept at rest for $30 \mathrm{~min}$ at room temperature before being centrifuged at $5,000 \times \mathrm{g}$ for $25 \mathrm{~min}$. The excess of water or oil was removed by tube inversion over tissue paper. The difference between the sample's weight before and after water or oil absorption was taken as the amount of water or oil absorbed. WHC or OHC were expressed as the percentage of water or oil absorbed by gram of sample.

\section{Emulsifying Activity Index (EAI)}

The emulsifying activity index (EAI; $\mathrm{m}^{2} \mathrm{~g}_{\text {solids }}{ }^{-1}$ ) was determined according to Pearce and Kinsella (1978) adjusted to laboratory conditions. A $0.2 \%$ protein dispersion was prepared, then $2 \mathrm{~mL}$ of a $0.1-\mathrm{M} \mathrm{NaCl}$ solution was added, obtaining a homogeneous paste. Then, a buffer solution was added with the corresponding $\mathrm{pH}$ up to $100 \mathrm{~mL}$ in a volumetric glass. The emulsion was prepared through the homogenization of the protein dispersion, by slowly adding corn oil for approximately $1 \mathrm{~min}$ at a $1: 3(v / v)$ rate, in a blender at medium speed. After that, $100 \mu \mathrm{L}$ aliquots of the emulsion were diluted in a $0.1 \%$ sodium dodecilsulfate solution, and its 500- $\eta \mathrm{m}$ absorbance was determined in spectrophotometer Varian visible UV 634-S. EAI was calculated through Eq. 3.

$\mathrm{EAI}=\frac{2 T}{(1-\theta) \times C}$

where $T$ is turbidity, $\theta$ is the fraction of oil spent to form the emulsion, and $C$ is the initial protein concentration.

Turbidity $(T)$ was calculated through Eq. 4 and the fraction of oil spent $(\theta)$ through Eq. 5 .

$T=\frac{2.303 \times A \times f}{L}$

where $A$ is absorbance, $f$ is the dilution factor, and $L$ is the optical path of the cubette.

$\theta=\frac{C-A-E-(B-C)}{C-A+(B-C)(1+E) \frac{D_{0}}{D_{S}}-E}$

where $A$ is the beaker's weight, $B$ is the beaker's weight with the emulsion, $C$ is the beaker's weight with dry material, $D_{0}$ is the oil's density, $D_{S}$ is the density of the protein dispersion, and $E$ is the concentration of the solute in mass unit by the mass of solvent.

Emulsion Stability (ES)

The stability of the emulsion was evaluated through the method described by Jeon et al. (1999) with modifications. The emulsion was heated for $30 \mathrm{~min}$ in a $90^{\circ} \mathrm{C}$ water bath and then cooled in an ice bath for the same interval. Then, 
$100 \mu \mathrm{L}$ aliquots of the emulsion subjected to the thermal treatment was diluted in a $0.1 \%$ sodium dodecilsulfate solution, and the absorbance was determined in a spectrophotometer, Varian visible UV 634-S at 500 ๆm. Equations 6 and 7 were used to calculate the index of emulsion stability.

$$
\Delta \mathrm{EAI} \%=\frac{\left(\mathrm{EAI}_{\max }-\mathrm{EAI}_{\min }\right)}{\mathrm{EAI}_{\max }} \times 100
$$

where $\mathrm{EAI}_{\max }$ is the highest value obtained for emulsions diluted soon after formation, and $\mathrm{EAI}_{\min }$ is the lowest value obtained after subjected to thermal treatment.

$\mathrm{ES}=\frac{1}{\Delta \mathrm{EAI} \%}$

\section{Determination of Amino Acids}

The determination of amino acids profile was conducted in an analyzer Beckman 6300 (Beckman Instruments Inc., Palo Alto, CA, USA). For triptophan determination, a hydrolysis procedure was performed with $4 \mathrm{~N} \mathrm{LiOH}$ for $24 \mathrm{~h}$ at $110^{\circ} \mathrm{C}$. For the other samples, the hydrolysis ran for $22 \mathrm{~h}$ at $110^{\circ} \mathrm{C}$ with $6 \mathrm{~N} \mathrm{HCl}$ under a nitrogen atmosphere. The analyses were conducted at the Protein Chemistry Centre at Ribeirão Preto Medicine College, USP, SP, Brazil.

\section{Results and Discussion}

\section{Raw Material Characterization}

Minced searobin presented a $\mathrm{pH}$ value of $6.7 \pm 0.2$, thus being in the ideal quality range. Muscle's $\mathrm{pH}$, according to authors Maldonado (1994) and Contreras-Guzmán (1994) is between 6.5 and 7.0 for fish caught at high seas. The same is stated by Martin et al. (1982) as pH is an important parameter and may define the quality of a food product.

The yield was assessed in two blocks, both as triplicates. Searobin fish provided a yield of $30.75 \pm 1.54 \%$ as fillet. Such low yield may be accounted by the fish's shape, as it has a very large head relative to the rest of the body.

Bluewing searobin fish muscle presented $16.9 \pm 0.5 \%$ of protein, $1 \pm 0.1 \%$ of ash, $0.3 \pm 0.1 \%$ of lipid, and $81.8 \pm$ $2.42 \%$ of moisture. Such results are in agreement with Contreras-Guzmán (1994) and Morais et al. (1992) who obtained for searobin a $79.1 \%$ moisture rate, $17.4 \%$ protein, $1.59 \%$ lipid, and a $1.4 \%$ ash rate.

\section{Specific Activity of Enzymes}

Figure 1 shows the activity of two enzymatic preparations with casein and searobin fillet as substrate. Casein is the most used protein substrate for determining the specific activity

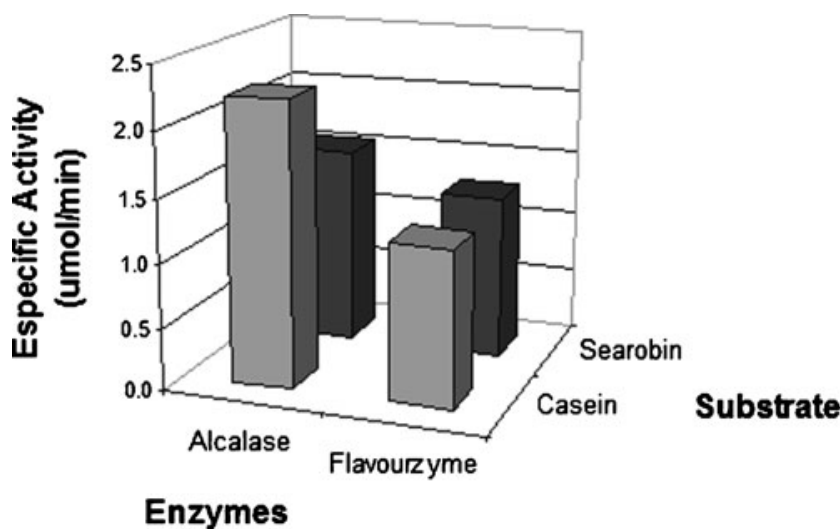

Fig. 1 Comparison of the specific activity of enzymes Alcalase and Flavourzyme measured with casein and searobin muscle as substrates

under neutral and alkaline conditions. However, since fish fillet is the main protein substrate used for the experiment, the comparison between them is relevant (Gildberg et al. 2002; Je et al. 2007; Liaset and Espe 2008). Results showed that Alcalase and Flavourzyme have different activities in both substrates, but most important is the fact that the specific activity was reduced when searobin was used as substrate, due to be more difficult to hydrolysis than casein. Gildberg et al. (2002) worked with cod protein and found specific activity values around $1 \mu \mathrm{mol}_{\mathrm{tyrosine}} \mathrm{min}^{-1}$ for the enzyme Alcalase, whereas the value obtained with the searobin substrate was $1.56 \mu \mathrm{mol}_{\mathrm{tyrosine}} \mathrm{min}^{-1}$ for the same enzyme. Therefore, the substrate upon which the enzyme will act is highly important for the determination of the final $\mathrm{DH}$.

The different activities in both substrate between Alcalase and Flavourzyme is clear; it happens at least for two reasons, the affinity of enzymes and substrate; Flavourzyme is an exoenzyme and delay more time than Alcalase, that is a endoenzyme, to reach the same hydrolysis.

\section{Solubility}

The results of enzymatic hydrolysate of searobin, obtained with Alcalase and Flavourzyme, and searobin muscle are showed in Fig. 2. We observed an increase in the solubility of the hydrolysate compared to searobin muscle.

Analyzing statistic data, with a 95\% confidence interval, a significant difference was observed among the samples and also between the $\mathrm{pH}$ values used. For $\mathrm{pH} 5$, the fish muscle presented solubility of $7.6 \%$, while the hydrolysate from Alcalase reached $40.5 \%$; this value show an increase of $433 \%$ in this property. For $\mathrm{pH} 11$, the increase of the solubility was $50 \%$. For the hydrolysate from Flavourzyme, the highest solubility attained to searobin muscle occurred at $\mathrm{pH} 5$, with a 395\% increase. According to Rebeca et al. (1991) and McNairney (1984), fish muscle provides lower solubility scores when compared with hydrolysate protein compounds. 


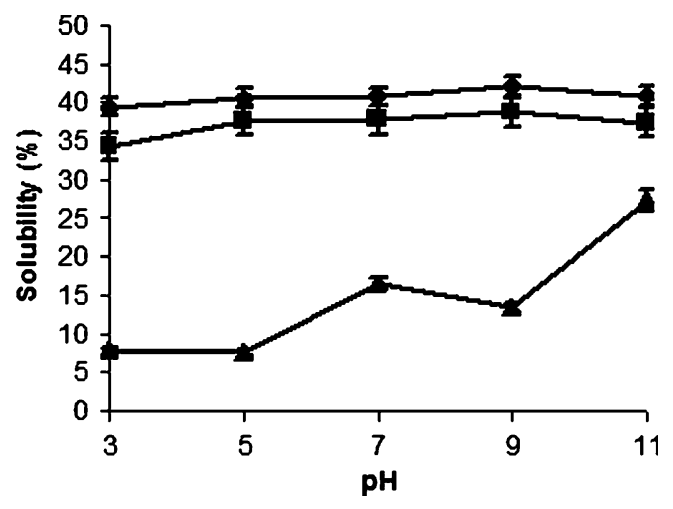

Fig. 2 Solubility of the hydrolysates and the raw material at different pHs. Alcalase (diamonds), Flavourzyme (squares), and searobin muscle (triangles)

Fish myofibrillar proteins are highly insoluble close the isoelectric point. The increase observed in solubility for the hydrolyzed is due to the smaller molecular size compared with the intact protein, and also to new carboxylic and amine groups from amino acids, which increase the hydrophilicity of the hydrolysate (Gauthier et al. 1993; Mahmoud 1994).

Production of high-solubility hydrolysate protein in a $\mathrm{pH}$ range is very interesting for food applications. Solubility can influence other functional properties of proteins, such as water and $\mathrm{OHC}$, because high solubility means smaller molecular size, and this is prejudicial to holding capacity. According to Kristinsson and Rasco (2000), the reduction in peptide size is what provides a high correlation rate between solubility and the DH.

The searobin muscle showed an increase in solubility with $\mathrm{pH}$ increased, while the other samples just showed a slight increase up to $\mathrm{pH}$ 9. It occurs because the solubility is higher in alkaline $\mathrm{pH}$, due to the number of negative charge residues (Cheftel et al. 1989).

Quaglia and Orban (1987a, b) also studied the properties of enzymatically hydrolysate compounds produced from sardine and concluded that Alcalase and papain produced highly soluble hydrolysate compounds.

\section{Water Holding Capacity (WHC) and Oil Holding Capacity (OHC)}

The raw muscle presented a WHC score of $2.37 \mathrm{~g}_{\text {water }} \mathrm{g}_{\text {protein }}{ }^{-1}$. The Alcalase hydrolysate digest from searobin showed a $2.95 \%$ increase in WHC relative to raw muscle, and the Flavourzyme hydrolysate compound showed an increase of $58.22 \%$. According to Orban et al. (1992), the high solubility leads to a decrease in the WHC of fish protein.

OHC found for the raw muscle was $0.73 \mathrm{~g}_{\text {oil }} \mathrm{g}_{\text {protein }}{ }^{-1}$, but the enzymatically hydrolysate compounds showed higher values; the Alcalase compound presented an $\mathrm{OHC}$ of $4.50 \mathrm{~g}_{\mathrm{oil}} \mathrm{g}_{\text {protein }}{ }^{-1}$, and for Flavourzyme, it was $5.52 \mathrm{~g}_{\mathrm{oil}}$ $\mathrm{g}_{\text {protein }}{ }^{-1}$. OHC for protein is correlated to the surface's hydrophobicity. Kristinsson and Rasco (2000) produced hydrolysate compounds from salmon, at different DH values, with both enzymes, Alcalase and Flavourzyme, and found the following respective values, 5.98 and $5.71 \mathrm{~mL}_{\text {oil }} \mathrm{g}_{\text {protein }}{ }^{-1}$ for a DH 5\%, 5.12 and $3.22 \mathrm{~mL}_{\text {oil }} \mathrm{g}_{\text {protein }}{ }^{-1}$ for a DH $10 \%$, and 3.86 and $2.95 \mathrm{~mL}_{\text {oil }} \mathrm{g}_{\text {protein }}{ }^{-1}$ for a DH $15 \%$. The capacity of the hydrolysate protein digest of absorbing oil is an important attribute that not only influences the taste of product but is also important for application in meat products, as substitutes or extending (Nakai 1983), and bakery products where oil absorbent is required (Idouraine et al. 1991). High OHC avoid phases separation and is essential for sausage elaboration, cake, mayonnaise, and other salad dressing (Chandi and Sogi 2007), improving the palatability and the taste retention of these products (Rodríguez-Ambriz et al. 2005). The hydrolysate compounds presented good oil absorption and may be used for such applications.

Emulsifying Activity Index (EAI) and Emulsion Stability (ES)

EAI values observed for samples of enzymatically hydrolysate compounds from searobin obtained with enzymes Alcalase and Flavourzyme and searobin muscle are shown in Table 2.

Alcalase hydrolysate showed the highest EAI at $\mathrm{pH} 3$, with the most stable emulsion being $0.0275 \%$ at $\mathrm{pH} 11$. Flavourzyme hydrolysate had the highest EAI at $\mathrm{pH} 11$ and the highest emulsion stability of $0.144 \%$ at $\mathrm{pH} 3$, as observed in Figure 3. The difference of emulsifying activity and stable emulsion between the hydrolysates probably occurred because of the amino acid profile of each one. According to Demetriades et al. (1997), the emulsifying properties of enzymatically hydrolysate compounds from fish are directly connected to the surface properties, or to how effectively the hydrolysate compound reduces the interfacial tension between the hydrophobic and hydrolytic components in food products. Liceaga-Gesualdo and Li-Chan (1999) found EAI scores of $12.16 \mathrm{~m}^{2} \mathrm{~g}_{\text {solids }}{ }^{-1}$, though they have not examined the EAI of hydrolysate digest from herring in relation to different $\mathrm{pH}$, but relative to stability along time.

The ANOVA results showed a significant difference $(p<0.05)$ in EAIs, $\mathrm{pH}$ values, and the interaction between samples and $\mathrm{pH}$.

In general, the factors that most influence the emulsifying properties are solubility, $\mathrm{DH}$, and the specificity of enzyme, as it influences the molecular size and the hydrophobicity of peptides resulting from hydrolysis (Nilsang et al. 2005; Slizyte et al. 2005). Therefore, the emulsifying properties in this study may have been affected by the high solubility of the hydrolysate compounds and also by the specificity of each enzyme. The stability of the emulsions was not statistically significant $(p<0.05)$ among $\mathrm{pH}$ scores. 
Table 2 Emulsifying activity index for enzymatically hydrolysates compounds and Bluewing searobin muscle as $\mathrm{m}^{2} \mathrm{~g}_{\text {solids }}{ }^{-1}$ at different $\mathrm{pHs}$

\begin{tabular}{lllr}
\hline $\mathrm{pH}$ & $\begin{array}{l}\text { Hydrolyzed } \\
\text { alcalase }\end{array}$ & $\begin{array}{l}\text { Hydrolyzed } \\
\text { Flavourzyme }\end{array}$ & $\begin{array}{l}\text { Searobin } \\
\text { muscle }\end{array}$ \\
\hline 3 & $54.38 \pm 0.78$ & $39.03 \pm 0.55$ & $26.16 \pm 0.59$ \\
5 & $28.06 \pm 0.45$ & $19.73 \pm 0.29$ & $71.33 \pm 0.69$ \\
7 & $25.29 \pm 0.95$ & $19.00 \pm 0.09$ & $56.72 \pm 0.68$ \\
9 & $20.46 \pm 0.54$ & $28.06 \pm 0.47$ & $162.25 \pm 0.89$ \\
11 & $19.88 \pm 0.75$ & $70.75 \pm 0.85$ & $123.22 \pm 0.99$ \\
\hline
\end{tabular}

\section{Amino Acid Profile}

Table 3 describes the amino acid composition of searobin hydrolysate from Alcalase and Flavourzyme.

The searobin enzymatically hydrolysate digest obtained with the enzyme Alcalase had a higher amino acid content than the one obtained from Flavourzyme. However, both showed essential amino acid amounts consistent with those found in the literature (Abdul-Hamid et al. 2002; Márquez et al. 2004).

The amino acid composition is important in protein hydrolysates because of the nutritional value (essential amino acids) and also has an influence on the functional properties.

Abdul-Hamid et al. (2002) obtained an enzymatically hydrolysate compound from tilapia by using the enzyme Alcalase and found values of $28.7 \mathrm{mg} \mathrm{g}_{\text {protein }}{ }^{-1}$ for lysine, $16.6 \mathrm{mg} \mathrm{g}_{\text {protein }}{ }^{-1}$ for isoleucine, $13.5 \mathrm{mg} \mathrm{g}_{\text {protein }}{ }^{-1}$ for tyrosine, and $13.2 \mathrm{mg} \mathrm{g}_{\text {protein }}{ }^{-1}$ for threonine. To the hydrophobic essential amino acids, such as phenylalanine, methionine, leucine, and valine, the values found in the present work were lower.

In an enzymatic hydrolysis, the capacity of the protease to cut peptide bonds is dependent on physical interactions between the substrate (raw material) and the enzyme (protease) in the aqueous environment present during

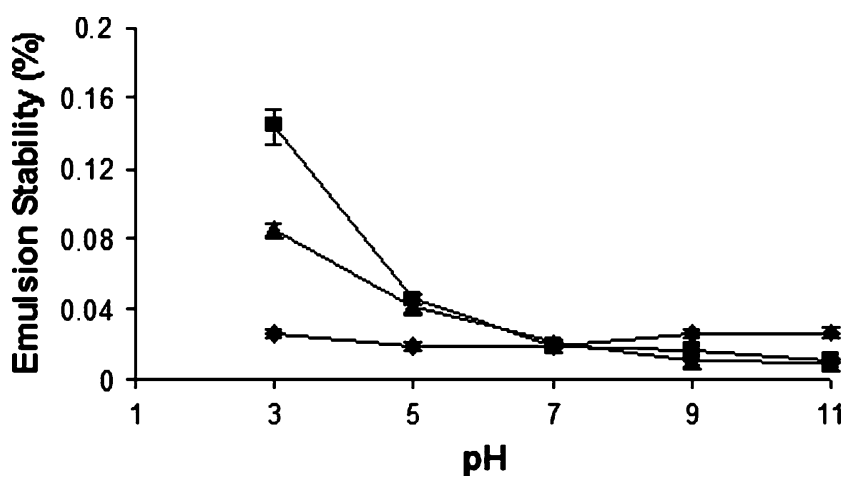

Fig. 3 Emulsion stability of the enzymatically hydrolyzed and raw material obtained at different $\mathrm{pHs}$. Alcalase (diamonds), Flavourzyme (squares), and raw fish muscle (triangles)
Table 3 Amino acid composition in enzymatically hydrolysate compounds (EHC) from Bluewing searobin obtained using Alcalase and Flavourzyme (mg $100 \mathrm{~g}_{\text {protein }}{ }^{-1}$ )

\begin{tabular}{lrrrr}
\hline Aminoacids & \multicolumn{2}{l}{ EHC Alcalase } & \multicolumn{2}{c}{ EHC Flavourzyme } \\
\hline Triptophan & 2.54 & \pm 0.00 & 3.67 & \pm 0.02 \\
Lysine & 35.54 & \pm 0.13 & 30.14 & \pm 0.06 \\
Histidine & 9.60 & \pm 0.05 & 8.54 & \pm 0.03 \\
Arginine & 25.83 & \pm 0.02 & 23.13 & \pm 0.07 \\
Aspartic acid & 37.24 & \pm 0.01 & 29.63 & \pm 0.14 \\
Threonine & 20.16 & \pm 0.08 & 18.50 & \pm 0.06 \\
Serine & 17.45 & \pm 0.03 & 16.25 & \pm 0.02 \\
Glutamic acid & 43.25 & \pm 0.14 & 33.34 & \pm 0.25 \\
Proline & 14.19 & \pm 0.06 & 12.44 & \pm 0.08 \\
Glycine & 16.30 & \pm 0.16 & 15.38 & \pm 0.01 \\
Alanine & 20.72 & \pm 0.12 & 18.95 & \pm 0.03 \\
1/2 Cysteine & 2.82 & \pm 0.00 & 2.59 & \pm 0.09 \\
Valine & 17.82 & \pm 0.11 & 16.27 & \pm 0.08 \\
Methionine & 12.22 & \pm 0.11 & 10.51 & \pm 0.07 \\
Isoleucine & 18.41 & \pm 0.17 & 16.94 & \pm 0.06 \\
Leucine & 30.24 & \pm 0.11 & 26.97 & \pm 0.08 \\
Tyrosine & 14.72 & \pm 0.02 & 13.73 & \pm 0.16 \\
Phenylalanine & 15.47 & \pm 0.14 & 14.75 & \pm 0.08 \\
\hline & & & &
\end{tabular}

hydrolysis. As a greater portion of the hydrophobic amino acids will reside within hydrophobic regions of the peptide chain in the raw materials (Chothia 1975), it is likely that the access for the protease to these hydrophobic regions might be limited (Chothia 1974).

The amount of phenylalanine found in the hydrolysates, bring up more options of food production to people that have some food restriction. Both hydrolysates showed an amount of phenylalanine around $15 \mathrm{mg} / 100 \mathrm{~g}$ of protein, which means that it could be used in food products to phenylketonuric patients. The products for phenylketonuric patients must have a lower phenylalanine concentration $(10-20 \mathrm{mg} / 100 \mathrm{~g}$ of product) (Poustie and Rutherford 2002).

\section{Conclusion}

The solubility of enzymatically hydrolysate compounds from searobin increased when compared to raw fish, showing a $42.1 \%$ solubility score with Alcalase and $38.7 \%$ with Flavourzyme, at $\mathrm{pH} 9$.

WHC was improved only in the searobin hydrolysate compound from Flavourzyme, reaching $3.75 \mathrm{~g}_{\text {water }} \mathrm{g}_{\text {protein }}{ }^{-1}$. The hydrolysate digest obtained from searobin with Alcalase did not show a significant difference relative to raw fish, being $2.44 \mathrm{~g}_{\text {water }} \mathrm{g}_{\text {protein }}{ }^{-1}$ and $2.37 \mathrm{~g}_{\text {water }} \mathrm{g}_{\text {protein }}{ }^{-1}$, respectively.

$\mathrm{OHC}$ was significantly improved by the fish hydrolysis. The results were 4.50 and $5.52 \mathrm{~g}_{\text {oil }} \mathrm{g}_{\text {protein }}{ }^{-1}$ for Alcalase and 
Flavourzyme, respectively, whereas the searobin muscle absorbed only $0.73 \mathrm{~g}_{\text {oil }} \mathrm{g}_{\text {protein }}{ }^{-1}$.

Emulsifying properties were not improved, as Alcalase provided values of 19.88 to $54.38 \mathrm{~m}^{2} \mathrm{~g}_{\text {solids }}{ }^{-1}$. The enzyme Flavourzyme obtained a higher EAI at $\mathrm{pH} 11$, $70.75 \mathrm{~m}^{2} \mathrm{~g}_{\text {solids }}{ }^{-1}$ and greater emulsion stability at $\mathrm{pH} 3$. Those results mean that the hydrolysate compounds were probably impaired by the high solubility level.

The amino acid profile obtained for both enzymatically hydrolysate digests shows that when included as ingredients in other food products, they will improve nutritional quality, as they carry relevant amounts of essential amino acids.

Acknowledgements The authors wish to thank the Coordination for Improvement of Superior Education Personal of Brazil (CAPES) and National Council for Scientific and Technological Development of Brazil $(\mathrm{CNPq})$ for financial support to carry out experiments.

\section{References}

Abdul-Hamid, A., Bakar, J., \& Bee, G. H. (2002). Nutritional quality of spray dried protein hydrolysate from Black tilapia (Oreochromis mossambicus). Food Chemistry, 78, 69-74.

Adler-Nissen, J. (1986). A review of food hydrolysis specific areas. In enzymic hydrolysis of food proteins (pp. 57-109). Copenhagen: Elsevier Applied Science Publishers.

AOAC. (1995). Official methods of analysis of international (16th ed.). Virginia: Arlington.

Casarin, F., Cladera-Olivera, F., \& Brandelli, A. (2008). Use of poultry byproduct for production of keratinolytic enzymes. Food and Bioprocess Technology, 1, 301-305.

Chandi, G. K., \& Sogi, D. S. (2007). Functional properties of rice bran protein concentrates. Journal of Food Engineering, 79, 592-597.

Cheftel, J. C., Cuq, J. L., \& Lorient, D. (1989). Proteinas alimentarías. Zaragoza: Acribia.

Chothia, C. (1974). Hydrophobic bonding and accessible surface-area in proteins. Nature, 9, 248-338.

Chothia, C. (1975). Structural invariants in protein folding. Nature, 8 , 254-304.

Contreras-Guzmán, E. S. (1994). Bioquímica de Pescados e Derivados, FUNEP: São Paulo.

Demetriades, K., Coupland, J. N., \& McClements, D. J. (1997). Physical properties of whey protein stabilized emulsions as related to $\mathrm{pH}$ and $\mathrm{NaCl}$. Journal of Food Science, 62, 342-347.

Diniz, F. M., \& Martin, A. M. (1996). Use of response surface methodology to describe the combined effects of $\mathrm{pH}$, temperature and $\mathrm{E} / \mathrm{S}$ ratio on the hydrolysis of dogfish (Squalus acanthias) muscle. International Journal of Food Science \& Technology, 31, 419-426.

Dumay, J., Donnay-Moreno, C., Barnathan, G., Jaquen, P., \& Bergé, J. P. (2006). Improvement of lipid and phospholipids recoveries from sardine (Sardina pilchardus) viscera using industrial proteases. Process Biochemistry, 41, 2327-2332.

El khalifa, A. E. O., Schiffler, B., \& Bernhard, R. (2005). Effect of fermentation on the functional properties of sorghum flour. Food Chemistry, 92, 1-5.

Gauthier, S. F., Paquin, P., Pouliot, Y., \& Turgeon, S. (1993). Surface activity and related functional properties of peptides obtained from whey proteins. Journal of Dairy Science, 76, $321-328$
Gildberg, A. (1993). Enzymatic processing of marine raw materials. Process Biochemistry, 28, 1-15.

Gildberg, A., Arnesen, J. A., \& Carlehög, M. (2002). Utilization of cod backbone by biochemical fractionation. Process Biochemistry, 38, 475-480.

Guerard, F., Sumaya-Martinez, M. T., Laroque, D., Chabeaud, A., \& Dufosse, L. (2007). Optimization of free radical scavenging activity by response surface methodology in the hydrolysis of shrimp processing discards. Process Biochemistry, 42, 1486-1491.

Hoyle, N., \& Merritt, J. H. (1994). Quality of fish protein hydrolysates from herring (Clupea harengus). Journal of Food Science, 59, 76-79.

Idouraine, A., Yense, S. B., \& Weber, C. W. (1991). Terapy bean flour, albumin and globulin fractions properties compared with soy protein isolate. Journal of Food Science, 56, 1316-1318.

Je, J. K. Y., Qian, Z. J., Byun, H. G., \& Kim, S. K. (2007). Purification and characterization of an antioxidant peptide obtained from tuna backbone protein by enzymatic hydrolysis. Process Biochemistry, $42,840-846$.

Jeon, Y. J., Hee-Guk, B., \& Se-Kwon, K. (1999). Improvement of functional properties of cod frame protein hydrolysates using ultrafiltration membranes. Process Biochemistry, 35, 471-478.

Kristinsson, H. G., \& Rasco, B. A. (2000). Kinetics of the hydrolysis of Atlantic salmon (Salmon solar) muscle proteins by alkaline proteases and a visceral serine protease mixture. Process Biochemistry, 36, 131-139.

Lempek, T. S., Martins, V. G., \& Prentice, C. H. (2007). Rheology of surimi-based products from fatty fish underutilized by the industry: Argentine croaker (Umbrina canosai). Journal of Aquatic Food Product Technology, 16(4), 27-44.

Liaset, B., \& Espe, M. (2008). Nutritional composition of soluble and insoluble fractions obtained by enzymatic hydrolysis of fish-raw materials. Process Biochemistry, 43, 42-48.

Liceaga-Gesualdo, A. M., \& Li-Chan, E. C. Y. (1999). Functional properties of fish protein hydrolysate from herring (Clupea harengus). Journal of Food Science, 64, 1000-1004.

Lowry, O. H., Rosebrough, N. J., Farr, A. L., \& Randall, R. J. (1951). Protein measurement with the Folin phenol reagent. Journal of Biological Chemistry, 193, 265-275.

McNairney, J. (1984). Modification of a novel protein product. Journal of Chemistry, Technology and Biotechnology. B: Biotechnology, 34, 206-214.

Maldonado, A. S. (1994). Comparación de quatro métodos para la recuperación de proteínas solubles eliminadas en la elaboración de surimi. Instituto Tecnológico Pesquero del Peru, 4, 15-26.

Mahmoud, M. I. (1994). Physicochemical and functional properties of protein hydrolysates in nutritional products. Food Technology, $58,89-95$.

Márquez, U. M. L., Mira, N. V. M., \& Neves, R. A. M. (2004). Caracterização de hidrolisados enzimáticos de pescado. Ciência e Tecnologia de Alimentos, 24, 101-108.

Martin, R. E., Flick, G. J., Hebard, C. E., \& Ward, D. D. (1982). Chemistry and biochemistry of marine food products. Westport: AVI Publishing Company.

Martins, V. G., Costa, J. A. V., \& Prentice-Hernández, C. (2009). Hidrolisado protéico de pescado obtido por vias química e enzimática a partir de corvina (Micropogonias furnieri). Química Nova, 32, 61-66.

Morais, C., Mantovani, D. M. B., \& Carvalho, C. R. L. (1992). Rendimento cárneo e composição química da ictiofauna acompanhante na captura do camarão sete barbas (Xiphopenaeus kroyeri). Coletânea do Instituto de Tecnologia de Alimentos, 22, 62-72.

Morr, V., German, B., Kinsella, J. E., Regenstein, J. M., Van Buren, J. P., Kilara, A., et al. (1985). A collaborative study to develop a standardized food protein solubility procedure. Journal of Food Science, 50, 1715-1718. 
Mullally, M. M., O’Callaghan, D. M., Fitzgerald, R. J., Donnelly, W. J., \& Dalton, J. P. (1995). Zymogen activation in pancreatic endoproteolytic preparations and influence on some whey protein characteristics. Journal of Food Science, 60, 227-233.

Nakai, S. (1983). Structure-function relationships of food proteins with an emphasis on the importance of protein hydrophobicity. Journal of Agricultural and Food Chemistry, 31, 676-683.

Nilsang, S., Lertsiti, S., Suphantharika, M., \& Assavanig, A. (2005). Optimization of enzymatic hydrolysis of fish soluble concentrate by commercial proteases. Journal of Food Engineering, 70, $571-578$.

Nolsoe, H., \& Undeland, I. (2009). The acid and alkaline solubilization process for the isolation of muscle proteins. Food and Bioprocess Technology, 2, 1-27.

Normah, I., Jamilah, B., Saari, N., \& Yaakob, B. C. M. (2005). Optimization of hydrolysis conditions for the production of threadfin bream (Nemipterus japonicus) hydrolysate by Alcalase. Journal of Muscle Foods, 16, 87-102.

Orban, E., Quaglia, G. B., Casini, I., Caproni, R., \& Moneta, E. (1992). Composition and functionality of sardine native proteins. Lebensmittel-Wissenschaft und Technologie, 25, 371-373.

Pearce, K. N., \& Kinsella, J. E. (1978). Emulsifying properties of proteins: evaluation of turbidimetric technique. Journal of Agriculture and Food Chemistry, 26, 716-723.

Poustie, U. J., \& Rutherford, P. (2002). Dietary intervention for phenylketnuria. Oxford: The Cochrane Library.

Quaglia, G. B., \& Orban, E. (1987a). Enzymatic solubilisation of proteins of sardine (Sardina pilchardus) by commercial proteases. Journal of Science and Food Agriculture, 38, 263269.
Quaglia, G. B., \& Orban, E. (1987b). Influence of the degree of hydrolysis on the solubility of protein hydrolysates from sardine (Sardina pilchardus). Journal of Science and Food Agriculture, 38, 271-276.

Rebeca, B. D., Peña-Vera, M. T., \& Díaz-Castañeda, M. (1991). Production of fish protein hydrolysates with bacterial proteases; yield and nutritional value. Journal of Food Science, 56, 309-314.

Rodríguez-Ambriz, S. L., Martínez-Ayala, A. L., Millán, F., \& DávilaOrtiz, G. (2005). Composition and functional properties of Lupinus campestris protein isolates. Plant Foods for Human Nutrition, 60, 99-107.

Rosa, C. S. (2000). Estudo das propriedades funcionais do colágeno obtido da pele de frango. Dissertação em Mestrado em Ciência e Tecnologia de Alimentos. Universidade Federal de Santa Maria. Santa Maria: UFSM.

Safari, R., Motamedzadegan, A., Ovissipour, M., Regenstein, J. M., Gildberg, A., \& Rasco, B. (2009). Use of hydrolysates from yellowfin tuna (Thunnus albacares) heads as a complex nitrogen source for lactic acid bacteria. Food and Bioprocess Technology. doi: 10.1007/s11947-009-0225-8.

Santos, S. D., Martins, V. G., Salas-Mellado, M., \& PrenticeHernández, C. (2009). Otimização dos parâmetros de produção de hidrolisados protéicos enzimáticos utilizando pescado de baixo valor comercial. Química Nova, 32, 72-77.

Skanderby, M. (1994). Protein hydrolysates: their functionality and applications. European Food Technology International, 10, 141-144.

Slizyte, R., Dauksas, E., Falch, E., Storrro, I., \& Rustad, T. (2005). Characteristics of protein fractions generated from hydrolysed cod (Gadus morhua) by-products. Process Biochemistry, 40, 2021-2033. 